Volume 16 (1) (2020) : 61-80
Jurnal Borne0 Administrator
p-issn : 1858-0300; e-issn : 2407-6767
http://samarinda.lan.go.id/jba
$\mathrm{DOl}: 10.24258 / \mathrm{jba.v16i1.603}$

\title{
KOLABORASI DAN E-LITERACY: KUNCI KEBERHASILAN INOVASI E-GOVERNMENT PEMERINTAH DAERAH
}

\section{COLLABORATION AND E-LITERACY: KEY SUCCESS INNOVATION OF LOCAL E-GOVERNMENT}

\author{
Mochammad Rozikin a, Wa Hesty ${ }^{b}$, dan Sulikah b
}

a Fakultas Ilmu Administrasi, Universitas Brawijaya

JI. MT. Haryono No. 163 Ketawanggede, Kec. Lowokwaru, Kota Malang

b Magister Ilmu Administrasi Publik, Universitas Brawijaya

Jl. MT. Haryono No. 163 Ketawanggede, Kec. Lowokwaru, Kota Malang

Email: mochrozikin@ub.ac.id; wahesty@student.ub.ac.id;

sulikahakhmad@student.ub.ac.id

Naskah diterima: 17 Desember 2019; revisi terakhir: 27 Februari 2020; disetujui 23 Maret 2020

How to Cite: Rozikin, Mochammad., Hesty, Wa., dan Sulikah. (2020). Kolaborasi dan E-Literacy: Kunci Keberhasilan Inovasi E-Government Pemerintah Daerah. Jurnal Borneo Administrator, 16 (1), 61-80. https://doi.org/10.24258/jba.v16i1.603

\begin{abstract}
E-government is a type of bureaucratic reform which not only highlights technological changes but also changes in the government system involving citizens in policy decisionmaking. Human resources, leadership and community engagement are critical success factors for innovation in e-government. Therefore, a local government innovation strategy is essential to enhance e-government growth through collaboration and $e$ literacy. Collaboration is a mechanism of collaboration between one government agency and other governments to jointly solve problems. Although e-literacy is a human resource capability in the learning process to understand a media. The methodology used was library research usingprevious research articles, books and website literature related to e-government innovation. The stage of the e-Government innovation strategy can be clarified by implementing the SWOT analysis of internal factors such as strength and weakness and external factors, namely opportunities and threats to establish SO strategy, ST strategy, WO strategy and WT strategy. The stages of innovation can be done through two procesess, namely collaboration and innovation.The mechanism of collaboration is carried out in order to overcome budgetary problems and to strengthen inter-related agencies in the development of e-government. The e-literacy process is conducted to enhance community participation and development of human capital through community socialization, training of trainers and comparative studies.
\end{abstract}

Keywords: Collaboration, E-Literacy, Innovation, Local E-Government 


\begin{abstract}
Abstrak
E-government merupakan sebuah bentuk reformasi birokrasi yang tidak hanya menekankan, baik pada perubahan penggunaan teknologi, tetapi juga perubahan sistem pemerintahan dalam pelibatan masyarakat untuk pengambilan keputusan. Faktor-faktor penentu keberhasilan inovasi e-governement adalah sumber daya manusia, leadership, dan partisipasi masyarakat. Oleh karena itu, diperlukan sebuah strategi inovasi dari Pemerintah Daerah untuk meningkatkan pengembangan e-government melalui kolaborasi dan e-literacy. Kolaborasi merupakan suatu proses tindakan kerjasama antara satu instansi pemerintah dengan pemerintahan lainnya guna memecahkan masalah secara bersama-sama. Sedangkan e-literacy merupakan suatu kemampuan sumber daya manusia untuk memahami suatu media dalam proses pembelajaran. Metode yang digunakan adalah studi pustaka, baik menggunakan jurnal penelitian terdahulu, buku maupun web literature yang berkaitan dengan inovasi e-government Pemerintah Daerah. Tahapan strategi inovasi e-government dapat dijelaskan melalui pengembangan dari analisa SWOT terhadap faktor-faktor internal, yaitu kekuatan dan kelemahan dan faktor eksternal, yaitu peluang dan ancaman sehingga menghasilkan strategi SO, strategi ST, startegi WO, dan strategi WT. Tahapan inovasi dapat dilakukan melalui dua proses yaitu kolaborasi dan inovasi. Proses kolaborasi dilakukan untuk mengatasi masalah anggaran dan penguatan antar instansi terkait dalam pengembangan inovasi $e$ government. Proses e-literacy dilakukan untuk meningkatkan partisipasi masyarakat dan pengembangan sumber daya manusia dengan cara sosialisasi kepada masyarakat, training of trainers, dan studi banding.
\end{abstract}

Kata kunci: Kolaborasi, E-Literacy, Inovasi, E-Government Pemerintah Daerah

\title{
A. PENDAHULUAN
}

Di Indonesia, implementasi e-government dilaksanakan setelah diterbitkannya Instruksi Presiden (Inpres) Nomor 3 tahun 2003 tentang Kebijakan dan Strategi Nasional Pengembangan E-government. Inpres ini dibuat sebagai dasar untuk menyamakan pandangan Pemerintah dalam menyelenggarakan sistem pemerintahannya sehingga terwujud pemerintahan yang transparan, akuntabel, efektif, dan efisien serta adanya pelibatan partisipasi masyarakat dalam pemerintahan. Sistem pemerintahan ini menjadi alat penghubung antara government dengan government $(G 2 G)$, government dengan staf (employee) (G2E), dan government dengan masyarakat (citizen) (G2C) (Maulana et al., 2019: 409-410).

Perkembangan e-government di Indonesia saat ini dirasa belum optimal meskipun telah dilaksanakan selama 16 tahun sejak 2003 dimana hasil implementasinya tidak sesuai dengan yang diharapkan. Berdasarkan e-government development global index (EDGI), perkembangan e-government di Indonesia tidak memberikan peningkatan yang signifikan dengan selisih peningkatan hanya sebesar 0,1 dari tahun pertama (2003) hingga tahun 2018. Kegagalan ini disebabkan oleh pemerintah kurang menaruh perhatian terhadap perkembangan e-government di Indonesia (Ordiyasa, 2015: 59). Hal ini dipertegas oleh penelitian selanjutnya mengenai analisis terhadap penggunaan web oleh pemerintah daerah dalam pengembangan e-government. Jumlah pemerintah daerah yang mengembangkan $e$ government telah mencapai tahapan pemanfaatan baru sebanyak 4 (empat) pemerintah daerah atau sebesar 0,7\% dari 548 pemerintah daerah yang ada di Indonesia (Yunita \& Aprianto, 2018: 334-335).

Dari fenomena tersebut, masih banyak tantangan dan peluang yang harus dihadapi dan dilakukan oleh pemerintah khususnya pemerintah daerah dalam penerapan dan 
pengembangan e-government. Oleh karena itu, perlu adanya suatu pembaharuan dan perbaikan yang dapat dilakukan oleh pemerintah daerah melalui inovasi. Dalam pelaksanaan inovasi, pemerintah daerah dituntut untuk berfikir kreatif dengan memanfaatkan sumber daya yang ada untuk menciptakan produk-produk inovasi pemerintah guna mendukung pelaksanaan e-government. Inovasi dalam pengambilan kebijakan dan kegiatan administrasi pemerintahan menjadi sangat penting, karena tanpa adanya inovasi, sistem pemerintahan akan mengalami kehancuran dan tidak efektif, kehilangan kemampuan untuk memerintah, dan menjadi sasaran kritik dan kegagalan (Farazmand, 2004: 19). Di Indonesia, dukungan nyata pemerintah guna memunculkan produk inovasi pemerintah dalam implementasi $e$ government dituangkan dalam Peraturan Pemerintah (PP) Nomor 38 Tahun 2017 tentang Inovasi Daerah. Kebijakan ini dijadikan sebagai stimulus (pendorong) bagi pemerintah daerah untuk melakukan inovasi terkait penyelenggaraan pemerintahan.

Beberapa faktor penting yang berpengaruh dalam pengembangan inovasi pemerintah daerah adalah sumber daya manusia, partisipasi masyarakat, aspek kepemimpinan, infrastruktur, manajemen informasi, dan lingkungan bisnis (swasta). Seperti dijelaskan oleh Muflihah \& Susanto (2017: 306-308) dan Andhika (2018: 210-213), yaitu bahwa kesuksesan pelaksanaan inovasi pemerintah daerah sangat dipengaruhi adanya kolaborasi penataan kelembagaan, aktor kebijakan, dan masyarakat. Selain itu, aspek kepemimpinan, infrastruktur jaringan informasi, manajemen informasi, lingkungan bisnis (swasta), sumber daya manusia, dan masyarakat juga menjadi faktor-faktor yang berpengaruh dalam pengembangan e-government pada pemerintah daerah khususnya di Indonesia Timur (Novita, 2014: 45-46; Sitokdana, 2019: 239-240; dan Wijaya et al., 2019: 284).

Untuk menjawab tantangan dari hambatan-hambatan di atas, perlu adanya suatu bentuk inovasi sebagai langkah nyata dalam pengembangan e-government di pemerintah daerah melalui kolaborasi dan e-literacy. Secara umum, konsep kolaborasi dalam e-government merupakan sebuah proses, sedangkan e-literacy adalah hasil dari proses tersebut. Kolaborasi dilakukan oleh pemerintah daerah guna pemenuhan sumber daya yang terbatas berkaitan dengan pemenuhan anggaran/finansial, sarana dan prasarana, dan sumber daya manusia (Wijaya et al., 2019: 282; dan Manurung \& Anza, 2017: 13). Sedangkan e-literacy dilakukan untuk mendukung pengembangan e-government yang berkaitan dengan teknologi, sumber daya manusia (pemimpin dan staf), lingkungan, dan masyarakat (Tomaszewicz, 2015: 51; dan Njenga, 2018: 3-7).

Kolaborasi dan e-literacy merupakan dua bentuk inovasi dalam pembaharuan penyelenggaraan pemerintahan daerah dalam pelaksanaan e-governenment seperti yang tertuang dalam Peraturan Pemerintah Nomor 38 Tahun 2017 tentang Inovasi Daerah. Inovasi ini bertujuan untuk meningkatkan kinerja penyelenggaraan daerah sehingga mempercepat terwujudnya kesejahteraan masyarakat melalui peningkatan pelayanan publik, pemberdayaan, dan peran serta masyarakat, serta peningkatan daya saing daerah (Kementerian Sekretariat Negara, 2017: 4). Bentuk inovasi yang dilakukan oleh pemerintah seharusnya mengandung beberapa kriteria di antaranya adalah: pembaharuan seluruh atau sebagian unsur dari inovasi, memberi manfaat bagi daerah dan masyarakat, tidak mengakibatkan pembebanan dan pembatasan pada masyarakat yang tidak sesuai dengan ketentuan perundang-undangan, dan inovasi tersebut juga dapat direplikasi.

Masih banyak instansi, khususnya pemerintah daerah yang belum mengembangkan inovasi dalam pemerintahannya. Dua contoh pemerintah kabupaten dan kota yang telah berhasil menyelesaikan tantangan ini adalah pemerintah Kota Surabaya dan Pemerintah Kabupaten Banyuwangi. Problem ini merupakan pekerjaan rumah bagi Pemerintah Indonesia khususnya pemerintah daerah untuk dapat melakukan perbaikan inovasi dalam 
pelayanan publik. Tujuan mendasar dalam penulisan artikel ini adalah untuk menggambarkan dan mendeskripsikan inovasi e-government yang dapat dilakukan oleh pemerintah daerah khususnya di Indonesia Timur dan bagaimanakah output yang dapat dihasilkan dari pengembangan inovasi e-government pemerintah daerah melalui kolaborasi dan e-literacy. Sebagai contoh, pemerintah daerah yang mulai membenahi dan mengembangkan inovasi e-government adalah Pemerintah Kota Ternate, Provinsi Maluku Utara dan Pemerintah Kabupaten Buru, Provinsi Maluku.

\section{B. METODE PENELITIAN}

Penulisan artikel ini menggunakan metode review literatur (studi pustaka). Literatur yang digunakan berasal dari buku dan jurnal penelitian terdahulu yang berkaitan dengan inovasi e-government. Data yang digunakan adalah data sekunder yang didukung dengan penelitian yang sejenis. Pengujian dilakukan dengan mengintegrasikan perspektif-perspektif dari berbagai temuan empiris sehingga penulisan ini semakin kuat karena dukungan berbagai perspektif keilmuan, yaitu dengan cara mendeskripsikan penelitian terdahulu untuk mendapatkan gambaran dan pendekatan yang digunakan untuk mencapai tujuan penelitan dan untuk membuktikan pertanyaan penelitian atau hipotesis yang dibangun (Snyder, 2019: 334-335). Literature review dapat berupa ringkasan sederhana dari sumber, namun memiliki pola organisasi dan mengabungkan ringkasan serta sintesis. Pada metode literature review, peneliti dituntut memiliki berbagai ketrampilan, seperti membuat definisi topik guna eksplorasi, memperoleh literatur yang tepat, menganalisis, dan mensintesis data dalam penulisan (Ramdhani et al., 2014: 50-53). Uraian dan kajian dari literature review diharapkan dapat memecahkan masalah pengembangan inovasi e-government pada Pemerintah khususnya pemerintah daerah.

Analisa data yang digunakan dalam tulisan ilmiah ini dengan menggunakan Analisa SWOT (Strenght, Weaknesses, Opportunity, dan Threat). Analisa SWOT digunakan untuk menggambarkan Pemerintah Daerah (pemda) yang telah melakukan inovasi dan dua Pemda yang belum melakukan inovasi secara maksimal. Dua pemda yang telah melakukan inovasi yakni Pemerintah Kota Surabaya dan Pemerintah Kabupaten Banyuwangi, sedangkan dua pemda yang belum melakukan inovasi, yakni Pemerintah Kota Ternate dan Pemerintah Kabupaten Buru. Hasil analisa SWOT yang didapatkan selanjutnya dianalisis untuk mendapatkan tahapan strategi pengembangan inovasi pada dua, yaitu Pemda Kota Ternate dan Kabupaten Buru. Strategi yang diinginkan dari analisa SWOT ini ada empat yaitu (1). Strategi SO yang bertujuan untuk menciptakan strategi yang menggunakan kekuatan untuk memanfaatkan peluang, (2). Strategi ST yang bertujuan untuk menciptakan strategi yang menggunakan kekuatan untuk mengatasi ancaman, (3). Strategi WO yang bertujuan untuk menciptakan strategi yang meminimalkan kelemahan untuk memanfaatkan peluang, dan (4). Strategi WT yang bertujuan untuk menciptakan strategi yang meminimalkan kelemahan dan menghindari ancaman (Rangkuti, 2004: 31-32).

\section{KERANGKA TEORI}

Penerapan Instruksi Presiden Nomor 3 Tahun 2003 terkait e-government merupakan sebuah inovasi dalam reformasi birokrasi di Indonesia yang menghendaki adanya perubahan penyelenggaraan pemerintahan yang lebih demokratis, transparan, dan akuntabel berbasis elektronik. Perubahan ini sebenarnya memberikan peluang yang sangat besar terhadap partisipasi masyarakat dalam proses pembangunan melalui penyaluran aspirasi terkait pelaksanaan pemerintahan. Selain itu, perkembangan teknologi informasi dan komunikasi 
turut membuka peluang untuk mengakses, mengelola dan memanfaatkan informasi dalam volume yang besar dengan cepat dan akurat (Widodo, 2019: 160).

Fenomena yang terjadi di lapangan menunjukkan bahwa implementasi e-government di Indonesia sudah meningkat secara kuantitatif, tetapi secara kualitas masih belum sebanding, sehingga masih terjadi perbedaan antara tujuan yang ingin dicapai oleh Pemerintah dan hasil yang didapatkan dari penerapan e-government ini sendiri (Sari \& Isnaeni, 2019: 86). Selain itu, kegagalan dalam pelaksanaan e-government diakibatkan oleh kesalahan dalam perubahan manajemen, yakni Pemerintah tidak memandang objek $e$ government (pemerintah/ pemerintah daerah) mempunyai kondisi yang unik sehingga hanya menerapkan model e-government yang umum (Sulistiyani \& Susanto, 2018: 40-41). Jika Pemerintah menginginkan kesuksesan pelaksanaan e-government sampai pada tingkat daerah Pemerintah harus mampu mengakomodasi kondisi kekhasan tiap-tiap daerah tersebut dengan memberikan peluang bagi pemerintah daerah melakukan inovasi dalam penerapan e-governement.

Inovasi yang dapat dilakukan pemerintah daerah adalah dengan menggunakan pendekatan konsep kolaborasi dan e-literacy. Konsep kolaborasi dipahami sebagai kerjasama antar aktor, antar organisasi, atau antar institusi dalam rangka pencapaian tujuan yang tidak bisa dicapai atau dilakukan secara independent (Sabaruddin, 2015: 25). Konsep kolaborasi yang diimplementasikan oleh pemerintah daerah dalam pelayanan publik akan memiliki kualitas yang lebih baik, menjangkau masyarakat luas hingga ke berbagai wilayah pelosok sehingga perbaikan kesejahteraan rakyat akan terwujud dengan sendirinya (Dwiyanto, 2015: 305). Di samping itu, konsep e-literacy perlu diterapkan pada pengembangan inovasi daerah. Konsep ini berkaitan erat dengan kualitas sumber daya manusia pada tiga aktor yang berperan pada konsep kolaborasi, yakni pemerintah, swasta, dan masyarakat. Informasi literacy dikenal pada level perencanaan strategis sebagai literasi digital (e-literacy) yang interpretasinya memiliki fokus pada aspek kemampuan dan pengetahuan sumber daya manusia, seperti memprediksi serta merupakan strategis prioritas untuk pembelajaran (Secker \& Coonan, 2013:28; dan Potter, 2004:68).

Beberapa faktor yang menjadi kendala dalam penerepan e-government terutama pada pemerintah daerah diantaranya adalah masih lemahnya sistem perencanaan dan keuangan, rendahnya kualitas sumber daya manusia, rendahnya budaya kerja organisasi, kurangnya sarana dan prasarana, lemahnya koordinasi dan kebijakan yang belum memadai (Maulana et al., 2019: 411; Jahidi \& Budiati, 2019: 544-545); dan Novita, 2014: 45). Rendahnya kualitas sumber daya manusia bisa disebabkan oleh faktor lemahnya kepemimpinan yang meliputi latar belakang pendidikan, pemecahan masalah dan pola hubungan/networking ( $\underline{\text { Yudha \& }}$ Susanto, 2019:5), dan juga rendahnya kemampuan e-literacy terhadap keberlanjutan data dan informasi (Jahidi \& Budiati, 2019: 545). Selain itu, kualitas sumber daya manusia ini sangat berpengaruh terhadap tumbuhnya inovasi, baik dari segi jumlah maupun jenis inovasi itu sendiri, terutama kemampuan pimpinan dalam mengorganisir lingkungan kerjanya untuk lebih inovatif (Yudha \& Susanto, 2019: 5). Dengan demikian dapat disimpulkan bahwa faktor utama yang menjadi hambatan dalam pengembangan e-government adalah sumber daya manusia.

Melihat kondisi penerapan e-government dan kendala-kendala yang dihadapi oleh pemerintah daerah, pemerintah telah membuat kebijakan dalam pengembangan $e$ government melalui PP Nomor 38 Tahun 2017 tentang Inovasi Daerah. Pelaksanaan inovasi daerah dan mengatasi kendala-kendala yang dihadapi dalam pengembangan e-government dapat dilakukan melalui dua cara, yaitu kolaborasi dan peningkatan e-literacy. Kolaborasi dapat dilakukan melalui government-to-government $(G 2 G)$ collaboration atau public private 
partnership untuk mengatasi masalah finansial dan sarana/prasarana. Sedangkan rendahnya e-literacy dapat ditingkatkan dengan cara pelatihan dan pendidikan (Jahidi \& Budiati, 2019: 546). Penerapan government-to-government $(G 2 G)$ collaboration dapat diterapkan dengan melakukan studi banding dengan mengadopsi penerapan e-government pada pemerintah lain yang lebih dahulu berhasil dalam penerapan e-government (Sitokdana, 2019: 240).

Adapun yang menjadi kerangka berfikir (framework) penelitian ini adalah seperti tertuang di dalam Gambar 1:

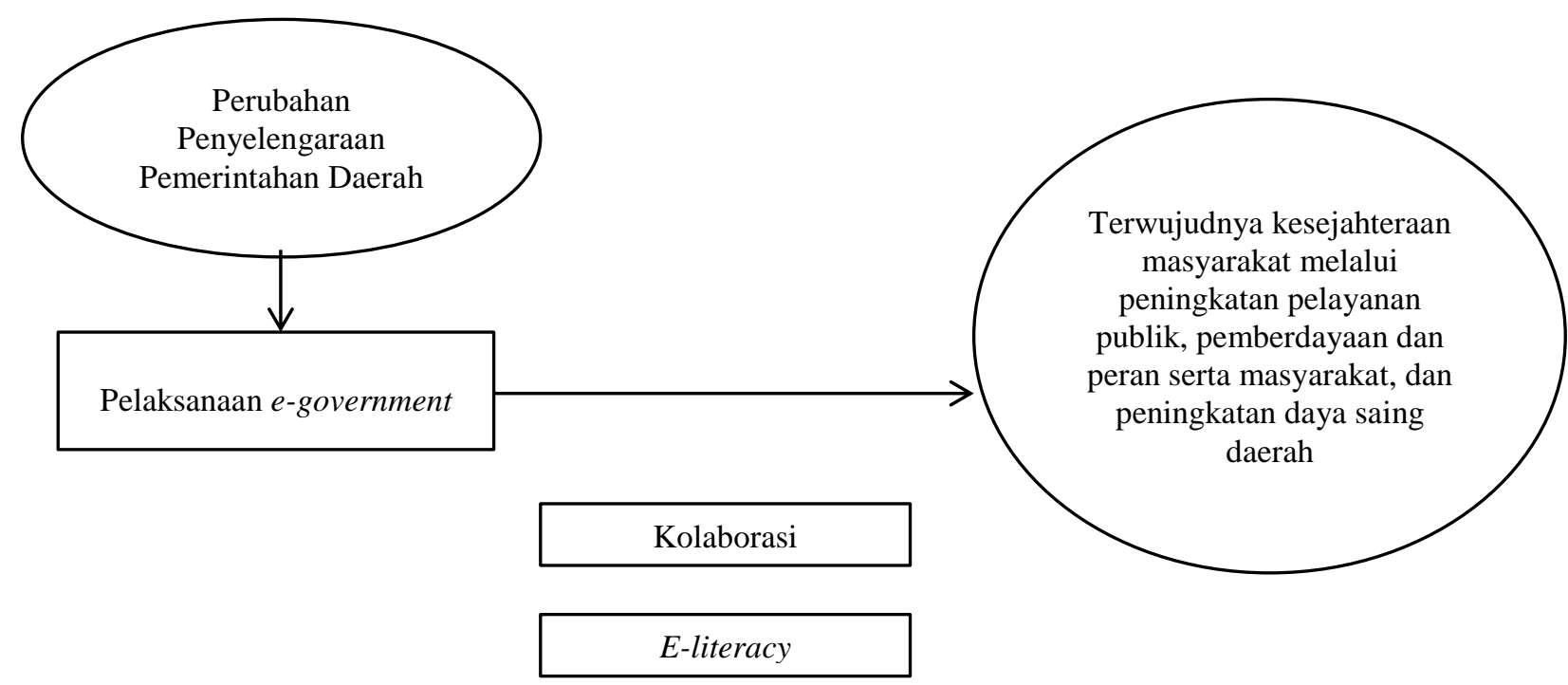

Gambar 1.

Kerangka berpikir (framework) (sumber : diolah dari PP Nomor 38 Tahun 2017)

\section{HASIL DAN PEMBAHASAN}

\section{Kondisi e-Government Pemerintah Daerah di Indonesia}

Penelitian mengenai implementasi e-government telah dilakukan sejak tahun 2001 oleh American Society for Public Administration (ASPA) dan the United Nations Division for Public Economics and Public Administration (UNDEEPA). Penelitian ini dilakukan terhadap 190 anggota United Nation (UN)/Perserikatan Bangsa-Bangsa (PBB) dan bertujuan untuk mengetahui sejauh mana dampak penggunaan internet terhadap pelaksanaan administrasi pemerintahan. Secara luas, e-government mencakup semua perangkat teknologi komunikasi dan informasi (ICT) dan aplikasi yang digunakan oleh sektor publik. Hasil penelitian yang didapatkan menunjukkan bahwa e-government merupakan pemanfaatan internet dan world-wide-web untuk mengirimkan informasi pemerintah dan pelayanan kepada masyarakat secara luas.

E-government telah diterapkan di Indonesia sejak tahun 2003 dengan diberlakukannya Inpres No.3 Tahun 2003. Berdasarkan Peraturan Presiden Nomor 95 Tahun 2018, egovernment disebut sebagai sistem pemerintahan berbasis elektronik (SPBE). SPBE adalah penyelenggaraan pemerintahan yang memanfaatkan teknologi informasi dan komunikasi untuk memberikan layanan kepada pengguna SPBE. Berdasarkan grafik pada Gambar 2, Indonesia memiliki nilai indeks pengembangan e-government yang fluktuatif berkisar antara 0,3 - 0,5 selama kurun waktu 15 tahun. 


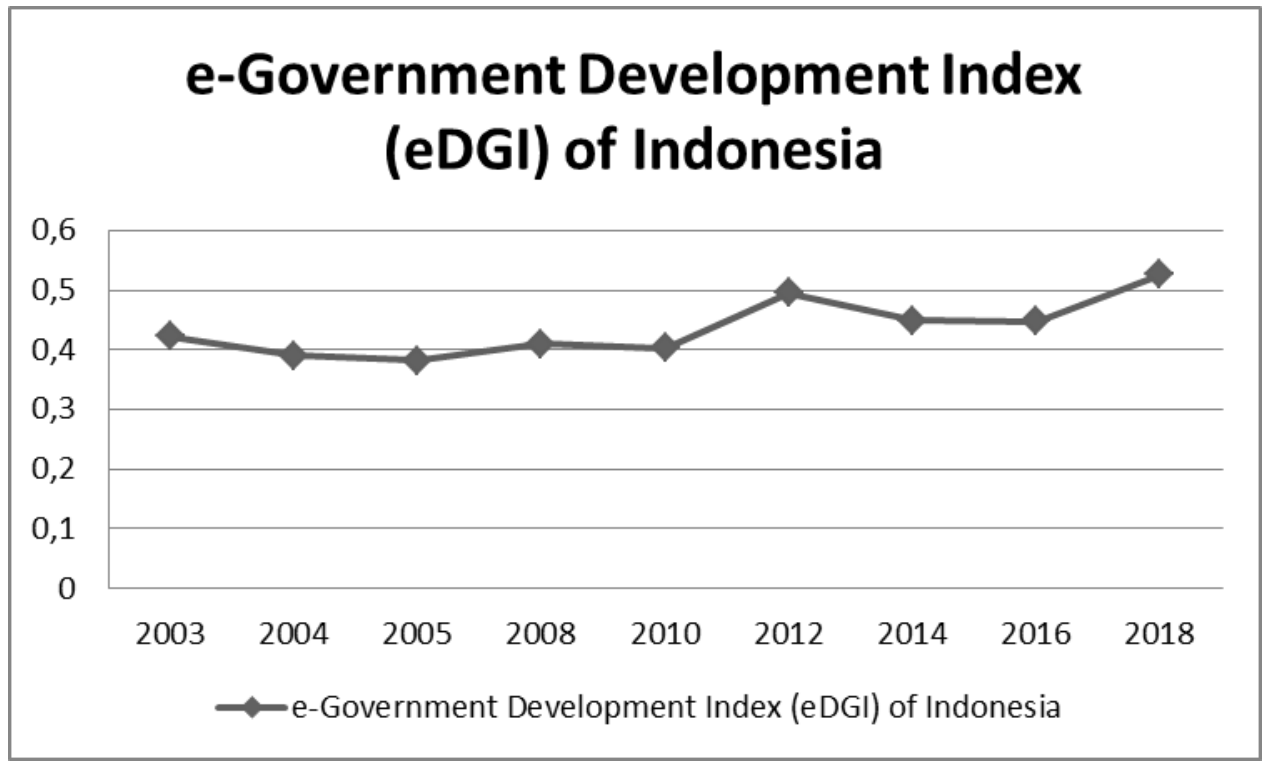

Gambar 2.

Grafik e-Government Development Index of Indonesia (Sumber: www.un.org)

Berdasarkan gambar 2 di atas, meskipun penerapan e-government di Indonesia sudah sampai tahun ke-15, tetapi hasil perkembangannya sendiri masih terkesan lambat dan tidak ada perkembangan yang begitu berarti. Selama kurun waktu tersebut indeks EGDI-nya hanya naik sekitar 0,1. Mengacu pada nilai indeks tersebut, UN menyebutkan bahwa penerapan $e$ government di Indonesia masuk dalam kategori low ke middle (United Nations, 2018: 6).

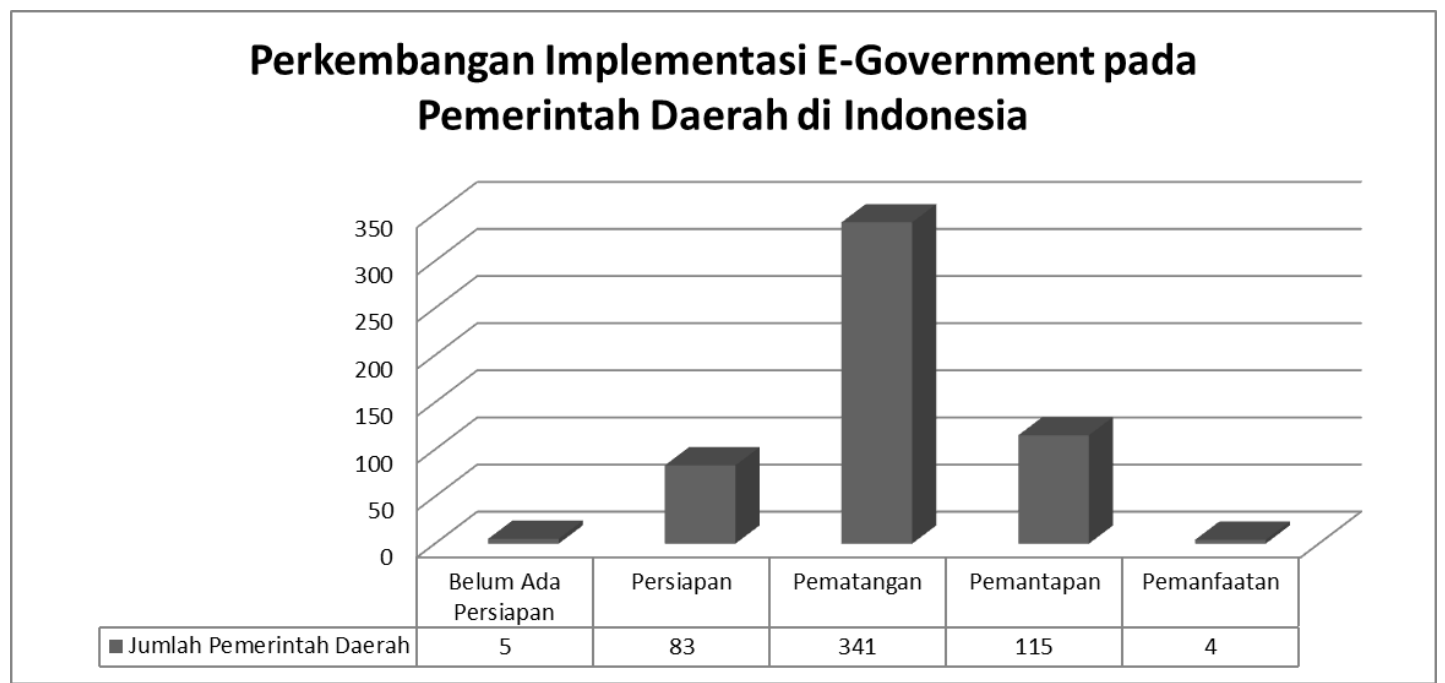

Gambar 3.

Grafik Perkembangan Implementasi E-Government pada Pemerintah Daerah di Indonesia Sumber : diolah dari (Yunita \& Aprianto, 2018: 334-335)

Kondisi terkini perkembangan e-government di Indonesia masih sangat lambat karena sebagian besar Pemerintah Daerah di Indonesia baru sampai pada tahap pematangan (Yunita \& Aprianto, 2018: 335). Penelitian ini didasarkan pada pelaksanaan e-government berdasarkan penggunaan website oleh pemerintah daerah. Gambaran tahapan pelaksanaan $e$ - 
government pada 548 pemerintah daerah baik, pemerintah provinsi, kabupaten maupun kota dapat dijelaskan seperti pada Gambar 3.

Secara umum, implementasi e-government pada lingkup pemerintah daerah di Indonesia telah mencapai semua tahapan, yaitu tahap persiapan, tahap pematangan, tahap pemantapan dan tahap pemanfaatan. Tahapan pematangan merupakan tahapan yang paling banyak dicapai oleh sebagian besar pemerintah daerah, sedangkan tahapan pemanfaatan merupakan tahapan yang paling sedikit dicapai. Di samping itu, masih terdapat sebanyak lima pemerintah daerah yang belum mengimplementasikan e-government. Hal ini menunjukkan bahwa pemerintah daerah terkesan kurang memberikan perhatian dan komitmen yang penuh pada pentingnya implementasi e-government di wilayahnya.

Ruang lingkup keberhasilan e-government harus mencakup empat hal hubungan interaksi, yakni : government to government $(\mathrm{G} 2 \mathrm{G})$, government to employee $(\mathrm{G} 2 \mathrm{E})$, dan government to citizen (G2C) (Sari \& Isnaeni, 2019: 85). G2G berkaitan dengan penyelesaian tugas dan urusan pemerintahan yang menghubungkan antar pemerintah/lembaga secara vertikal. G2E adalah tipe hubungan interaksi secara internal antara pemerintah dan pegawai. G2C merupakan perwujudan interaktif antara pemerintah dan komunitas masyarakat. Hal ini berbanding terbalik dengan fakta yang ada pada pemerintah daerah di Indonesia, yang saat ini baru mencapai pada tahapan interaksi sebatas G2G dan G2E, sedangkan G2C belum terlalu optimal pemanfaatannya dalam implementasi e-government di pemerintah daerah.

Secara umum, implementasi e-government di Indonesia masih dalam tahapan G2G. Tahapan ini masih terbatas dalam hal interaksi dengan masyarakat dan masih belum sepenuhnya ke tahap transaksi mengingat masih banyak pemerintah daerah yang belum menerapkan e-government. Keterbatasan interaksi ini terlihat dari belum mampunya pemerintah daerah untuk menerapkan pelayanan yang dekat dengan masyarakat (Hardjaloka, 2014: 444). Hal ini menjadi gambaran bahwa implementasi e-government pada pemerintah daerah di Indonesia tidak berdasarkan konsep dan kebutuhan yang diharapkan yaitu, pelayanan pemerintah yang dekat dengan masyarakat.

Pencapaian implementasi e-government ini masih jauh dari target keberhasilan yang diharapkan. Kegagalan e-government disebabkan oleh kesalahan dalam perubahan manajemen budaya organisasi. Model implementasi e-government yang diterapkan oleh Pemerintah Indonesia masih bersifat general tanpa melihat situasi dan kondisi (kearifan lokal) pemerintah daerah yang ada (Sulistiyani \& Susanto, 2018: 41). Situasi dan kondisi dalam satu wilayah dengan wilayah yang lain bisa berbeda, hal ini bisa sangat dipengaruhi oleh kearifan lokal tiap-tiap wilayah, seperti budaya, dan adat istiadat. Selain itu, sebagian besar aplikasi yang dibuat dan digunakan pada implementasi e-government di daerah masih hanya karena tuntutan perintah dari seorang pemimpin tanpa melihat nilai dari pemanfaatannya (kebutuhannya), sehingga faktor leadership atau kepemimpinan seorang pimpinan sangat mempengaruhi terlaksananya implementasi e-government.

Kemampuan seorang pimpinan menentukan bagaimana pimpinan tersebut mampu dalam memanfaatkan informasi dan teknologi untuk mencapai tujuan organisasi yang disebut juga dengan e-leadership. Kualitas e-government dari setiap pemerintahan sangat dipengaruhi oleh kualitas e-leadership tiap pimpinan. Pimpinan daerah yang memiliki $e$ leadership dalam memimpin daerahnya dapat terlihat dari kepemimpinan yang kuat, visi dan misi kepemimpinannya, selaras tujuan informasi teknologi dan strateginya, komitmennya, dan fungsi kepemimpinannya. Kemampuan pimpinan dalam menerapkan e-leadership juga sangat dipengaruhi oleh latar belakang pendidikan, penyelesaian masalah, dan hubungan serta jaringan yang luas (Yudha \& Susanto, 2019: 5-6). Lemahnya faktor leadership yang 
dimiliki oleh pimpinan daerah tentu mampu mempengaruhi lambatnya implementasi $e$ governement.

Selain faktor leadership, hambatan yang juga dapat mempengaruhi implementasi $e$ government adalah kemampuan sumber daya manusia dalam mengubah pola pikir. Kemampuan sumber daya manusia (SDM) yang dibutuhkan tidak hanya dalam kemampuan penguasaan aspek informasi dan teknologi, tetapi pada perubahan aspek budaya organisasi. Adanya penurunan pelayanan publik dari pemerintah (supply) dan meningkatnya tuntutan masyarakat untuk dilayaninya (demand), menciptakan suatu permasalahan atau gap dalam pelaksanaan pemerintahan (governance) di Indonesia (Maulana et al., 2019: 408-409). Terhadap adanya perubahan aspek budaya organisasi terutama dalam implementasi $e$ government, SDM dituntut untuk dapat menerima dan mengimbangi dengan kinerja yang baik. Oleh karena itu, dibutuhkan suatu perubahan ke arah yang lebih baik dalam penerapan e-government melalui inovasi pelayanan publik.

\section{Inovasi e-Government Pemerintah Daerah di Indonesia}

Inovasi pemerintah merupakan suatu ide/gagasan/metode ataupun peralatan yang digunakan pemerintah dalam melakukan perbaikan terhadap perumusan dan pelaksanaan kebijakan. Inovasi dalam pemerintahan merupakan sebuah ide kreatif dalam melalukan pembaharuan dalam sistem pemerintahan guna meningkatkan kinerja pemerintahan itu sendiri. Dalam implementasi e-government, penerapan inovasi dalam pengambilan kebijakan dan tata kelola pemerintahan akan mampu mempertahankan kinerja pemerintah tersebut sehingga bisa lebih efektif dan memenuhi keinginan masyarakat/publik. Jadi, hal tersebut akan jauh dari target kritik masyarakat terhadap pelaksanaan pelayanan publik.

Menurut Cornell University et al. (2019: 36), kondisi inovasi Pemerintah Indonesia saat ini berada pada urutan ke-85 dunia dan dua terbawah di tingkat Asia (Gambar 4). Fakta ini membuktikan bahwa masih banyak pemerintah daerah yang belum melakukan inovasi dalam implementasi e-government di Indonesia. Ini juga merupakan salah satu tantangan dan peluang pemerintah daerah untuk saling mendukung dalam mengembangkan inovasi. Beberapa faktor yang sangat berpengaruh dalam pengembangan inovasi pemerintah daerah adalah sumber daya manusia, partisipasi masyarakat serta institusi pemerintah itu sendiri. Selain itu, kesuksesan pelaksanaan inovasi pemerintah sangat penting dengan adanya dukungan oleh aktor kebijakan dan masyarakat (Andhika, 2018: 217; dan Muflihah \& Susanto, 2017: 309).

Tabel 1.

Perbandingan Indeks Inovasi Indonesia di tingkat Dunia dan Asia

\begin{tabular}{lcc}
\hline \multicolumn{1}{c}{ Country } & Rank Global & Rank Region \\
\hline Singapore & 8 & 1 \\
Malaysia & 35 & 8 \\
Viet Nam & 42 & 9 \\
Thailand & 43 & 10 \\
Philippines & 54 & 12 \\
Brunei Darussalam & 71 & 13 \\
Indonesia & 85 & 14 \\
Cambidoa & 98 & 15 \\
Total & 129 & 15 \\
\hline Sumber : diolat
\end{tabular}

Sumber : diolah dari (Cornell University et al., 2019: 35-40) 
Pemerintah Indonesia melalui Kementerian Pendayagunaan Aparatur Negara dan Reformasi Birokrasi setiap tahun melakukan kompetisi antarpemerintah/lembaga guna mendukung dan mendorong berkembangnya inovasi di institusi pemerintahan. Kompetisi pada tahun 2019 telah menghasilkan sebanyak 99 inovasi pada bidang pelayanan publik (Gambar 4). Pelaksanaan kompetisi inovasi pelayanan publik ini juga menjadi pendorong bagi pemerintah daerah untuk berlomba-lomba, baik melakukan perubahan maupun pembaharuan dalam pelayanan publik, sehingga mampu mendukung pelaksanaan $e$ government menjadi lebih baik. Dalam pelaksanaan kompetisi ini, pemerintah mencoba menggali kondisi pelayanan publik yang masih perlu ditingkatkan dengan melihat kekhasan wilayah dan memanfaatkan sumber daya yang ada.

Pada Gambar 4 terlihat adanya ketimpangan kondisi inovasi pelayanan publik. Dari 99 inovasi pelayanan publik masih sangat didominasi oleh pemerintah daerah dari Jawa dan Bali (DKI Jakarta, Banten, Jawa Barat, Jawa Tengah, DIY, Jawa Timur, dan Bali) sedangkan wilayah lain hanya sebagain kecil. Adanya ketimpangan kondisi ini merupakan sebuah fakta bahwa adanya ketimpangan kemampuan sumber daya manusia dalam melakukan inovasi daerah. Beberapa contoh pemerintah daerah yang telah berhasil dalam pelaksanaan inovasi e-government, antara lain adalah Pemerintah Kota Surabaya dan Pemerintah Kabupaten Banyuwangi.

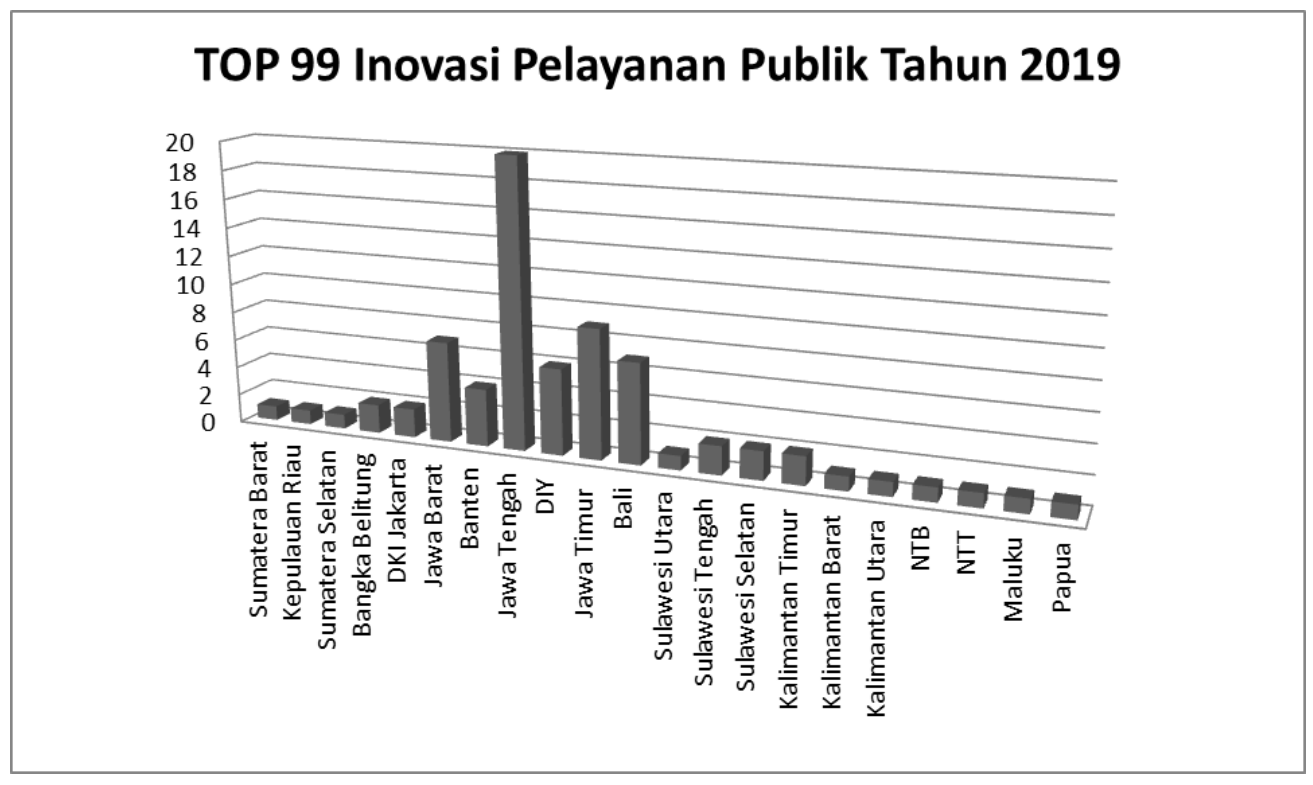

Gambar 4.

Top 99 Inovasi Pelayanan Publik Tahun 2019

(Sumber : diolah dari Kementerian Pendayagunaan Aparatur Negara dan Reformasi

Birokrasi, 2019: 1-7)

Salah satu pengembangan inovasi yang dilakukan Pemerintah Kota Surabaya adalah pengembangan aplikasi $e$-wadul. Inovasi ini mulai dikembangkan pada tahun 2016 dan digunakan sebagai alat untuk melaporkan segala keluhan masyarakat terkait pelayanan publik Pemerintah Kota Surabaya, sehingga pemerintah meningkatkan kualitas pelayanan publiknya. Di samping itu, Pemerintah Kabupaten Banyuwangi juga melakukan inovasi $e$ government pada sistem pemerintahannya. 
Didasarkan pada evaluasi kualitas informasi website, Pemerintah Daerah Provinsi Maluku, Maluku Utara, dan Papua Barat dengan menggunakan sepuluh dimensi, di antaranya akurasi, konsistensi, ketetapatan waktu, kesempurnaan, reliabilitas, ketersediaan, relefansi, kepercayaan, efesiensi, dan nilai tambah belum cukup memberikan/menyediakan kualitas pelayanan publik berbasis web (Sitokdana, 2019: 240). Penelitian ini merupakan gambaran dari pengembangan inovasi pemerintah daerah yang belum terlaksana dengan baik sehingga menjadi tantangan dan hambatan dari Pemerintah Indonesia khususnya pemerintah daerah untuk melakukan inovasi dalam implementasi e-government. Dua pemerintah daerah yang belum melakukan inovasi e-government di wilayah timur Indonesia adalah Pemerintah Kota Ternate, Provinsi Maluku Utara dan Pemerintah Kabupaten Buru, Maluku.

\section{Hambatan dan Peluang dalam Pengembangan Inovasi E-government}

Pemerintah Daerah (Pemda) Kota Ternate dan Kabupaten Buru merupakan dua contoh pemda di wilayah timur Indonesia yang mulai melakukan perbaikan inovasi dalam sistem pemerintahannya. Dua pemerintah daerah tersebut sudah menerapkan e-government, tetapi inovasi yang diterapkan masih belum optimal sehingga mempengaruhi kualitas pelayanan publik (Sitokdana, 2019: 240).

Beberapa faktor yang menjadi penghambat dalam mengembangkan inovasi $e$ government di pemerintah daerah khususnya di Indonesia Timur adalah sarana dan prasarana (infrastruktur), perencanaan, sumber daya manusia (SDM), leadership (kepemimpinan), dan kurangnya pelibatan masyarakat. Faktor penghambat yang dapat mempengaruhi kualitas inovasi e-government, khususnya kualitas informasi dari website di antaranya adalah aspek kepemimpinan, infrastruktur jaringan informasi, manajemen informasi, lingkungan bisnis (swasta), sumber daya manusia, dan masyarakat (Sitokdana, 2019: 239-240). Faktor yang berpengaruh terhadap hambatan dalam pengembangan inovasi e-government adalah lemahnya kepemimpinan, kurangnya sumber daya manusia, kesenjangan digital, kurangnya koordinasi, dan lemahnya manajemen (Novita, 2014: 46).

Tabel 2.

SWOT Terhadap Pelaksanaan Inovasi E-Government pada Pemkot (Pemerintah Kota) Surabaya, Pemkab (Pemerintah Kabupaten) Banyuwangi, Pemkot (Pemerintah Kota) Ternate, Pemkab (Pemerintah Kabupaten) Buru

\begin{tabular}{|c|c|}
\hline Strengths & Weaknesses \\
\hline $\begin{array}{l}\text { Surabaya } \\
\text { - Daerah urban yang berkelanjutan } \\
\text { (sustainable development) } \\
\text { ( } \text { Rukmananda, 2017: 1) } \\
\text { - Pemimpin yang berwawasan inovasi }\end{array}$ & $\begin{array}{l}\text { Surabaya (Widodo, 2019: 163) } \\
\text { - } \quad \text { Kendala jaringan teknis } \\
\text { - } \quad \text { Kurangnya sosialisasi di masyarakat }\end{array}$ \\
\hline $\begin{array}{l}\text { Banyuwangi } \\
\text { - Pemda ter-inovasi se Indonesia } \\
\text { (Fanani, 2019: 1) } \\
\text { - Paradigma "Sunrise of Java" (Fikri, } \\
\text { 2017: 333) }\end{array}$ & $\begin{array}{l}\text { Banyuwangi (Widodo, 2019: 163) } \\
\text { - } \quad \text { Kendala jaringan teknis } \\
\text { - } \quad \text { Kurangnya sosialisasi di masyarakat }\end{array}$ \\
\hline $\begin{array}{l}\text { Ternate } \\
\text { - Jumlah usia penduduk produktif yang } \\
\text { tinggi (Badan Pusat Statistik (BPS), } \\
\text { 2019b: } 56 \text { ) }\end{array}$ & $\begin{array}{l}\text { Ternate } \\
\text { - Jumlah SDM dan kualitas yang masih } \\
\text { rendah }\end{array}$ \\
\hline
\end{tabular}


- Penetapan Ternate sebagai kota kreatif (Marsaoly, 2019: 1)

- Dukungan penguatan jaringan informasi
- Kondisi geografis Kota Ternate yang kepulauan (Badan Pusat Statistik (BPS), 2019b: 7-8)

- Rendahnya $e$-literacy di masyarakat

- Informasi yang tidak up to date

- Pengembangan aplikasi belum terintegrasi
Buru

- Jumlah usia penduduk produktif yang tinggi (Badan Pusat Statistik (BPS), 2019a: 60)

- Kemampuan SDM

- Penguatan jaringan informasi

- Pemimpin yang tegas

\section{Opportunities}

Surabaya

- Kebijakan untuk pelaksanaan $e$ government Inpres 3/2003, PP no $38 / 2017$ tentang inovasi daerah

- Persaingan yang sehat antarpemerintah daerah untuk meraih penghargaan

\begin{tabular}{l}
\hline Banyuwangi \\
- Kebijakan untuk pelaksanaan $e$ - \\
government Inpres 3/2003, PP no \\
38/2017 tentang inovasi daerah \\
- Persaingan yang sehat antarpemerintah \\
daerah untuk meraih penghargaan
\end{tabular}

Ternate

- Kebijakan untuk pelaksanaan $e$ government Inpres 3/2003, PP no $38 / 2017$ tentang inovasi daerah Buru

- Motivasi SDM yang masih rendah

- Rendahnya e-literacy di masyarakat

- Sarana dan prasarana yang masih belum memadai (kelistrikan)

Persaingan yang sehat antarpemerintah daerah untuk meraih penghargaan

- Program inovasi daerah Ternate Smart Island (Anonim, 2019b: 1)

\section{Buru}

- Kebijakan untuk pelaksanaan $e$ government Inpres 3/2003, PP no $38 / 2017$ tentang inovasi daerah

- Persaingan yang sehat antarpemerintah daerah untuk meraih penghargaan

- Program inovasi daerah Buru Kalesang Data (Buka Data) (Anonim, 2019a: 1)

Sumber: diolah dari (Rukmananda, 2017: 1), (Fanani, 2019: 1), (Fikri, 2017: 333), (Badan Pusat Statistik (BPS), 2019b: 56), (Marsaoly, 2019: 1), (Badan Pusat Statistik (BPS), 2019a: 60), (Widodo, 2019: 163), (Badan Pusat Statistik (BPS), 2019b: 7-8), (Anonim, 2019b: 1), (Anonim, 2019a: 1)
Surabaya

- Kebutuhan masyarakat terhadap pelayanan publik terus meningkat

- Perubahan global yang sangat cepat

- Aspek politik daerah

\section{Banyuwangi}

- Kebutuhan masyarakat terhadap pelayanan publik terus meningkat

- Perubahan global yang sangat cepat

- Aspek politik daerah

Ternate

- Aspek politik daerah

- Perubahan global yang sangat cepat

\section{Buru}

- Aspek politik daerah

- Perubahan global yang sangat cepat 
Pada Tabel 2 di atas, merupakan kondisi SWOT yang terjadi pada empat unit analisis saat ini, yaitu Pemkot Surabaya, Pemkab Banyuwangi, Pemkot Ternate, dan Pemkab Buru. Meskipun pada dua unit analisis, yaitu Pemkot Surabaya dan Pemkab Banyuwangi termasuk dua Pemerintah Daerah yang tergolong berhasil dalam pelaksanaan e-government dan inovasinya, keduanya juga masih memiliki beberapa ancaman dan kelemahan yang bisa menghambat pelaksanaan e-government. Ancaman dan hambatan yang bersifat eksternal juga sangat mempengaruhi pelaksanaan e-government yang terjadi di pemerintah daerah lainnya seperti pada Pemkot Ternate dan Pemkab Buru.

Analisis terhadap faktor-faktor SWOT pada Pemkot Ternate dan Pemkab Buru dijelaskan pada Tabel 3 guna mendapatkan empat strategi, yakni strategi SO, strategi ST, strategi WO, dan strategi WT. Keempat strategi ini dianalisis guna mendapatkan langkah dan strategi yang optimal dalam mengembangkan inovasi e-government di dua pemerintah daerah tersebut.

Tabel 3.

Analisa SWOT

\begin{tabular}{|c|c|c|}
\hline $\begin{array}{l}\text { EFAS } \\
\text { IFAS }\end{array}$ & Strengths (S) & Weaknesses (W) \\
\hline Opportunities (O) & $\begin{array}{l}\text { - } \begin{array}{l}\text { Pemanfaatan } \\
\text { penguatan dukungan } \\
\text { informasi jaringan }\end{array} \\
\text { pengoptimalan } \\
\text { pelaksanaan kebijakan } e \text { - } \\
\text { government dan program } \\
\text { inovasi daerah } \\
\text { - } \begin{array}{l}\text { Kebijakan penetapan } \\
\text { kota kreatif sebagai }\end{array} \\
\text { upaya menciptakan } \\
\text { persaingan yang sehat } \\
\text { antardaerah }\end{array}$ & 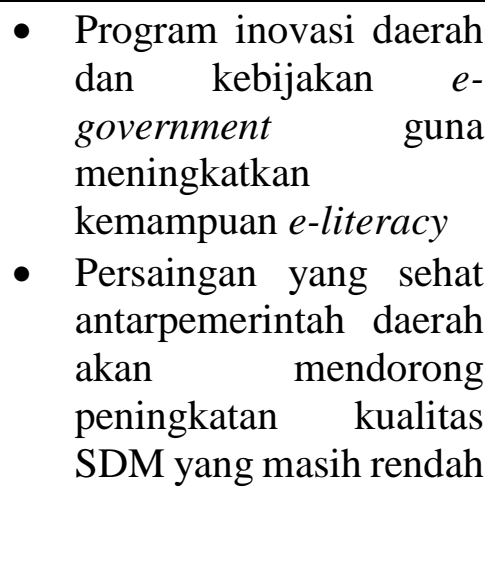 \\
\hline Treaths $(\mathrm{T})$ & $\begin{array}{l}\text { Pengoptimalan keterlibatan } \\
\text { penduduk usia produktif } \\
\text { yang tinggi dalam } \\
\text { mengatasi ancaman } \\
\text { perubahan global yang } \\
\text { sangat cepat dan ancaman } \\
\text { aspek politik daerah }\end{array}$ & $\begin{array}{l}\text { Meminimalisir perubahan } \\
\text { global yang sangat cepat } \\
\text { dengan } \text { meningkatkan } \\
\text { kualitas } \text { SDM dan } \\
\text { kemampuan } \\
\text {-literacy }\end{array}$ \\
\hline
\end{tabular}

Sumber: diolah dari Tabel 2. SWOT terhadap pelaksanaan inovasi e-government pada Pemkot Surabaya, Pemkab Banyuwangi, Pemkot Ternate, Pemkab Buru

Pada strategi SO terdapat dua strategi yang dapat dijalankan, yakni pemanfaatan dukungan penguatan jaringan informasi guna pengoptimalan pelaksanana kebijakan $e$ government dan program inovasi daerah dan kebijakan penetapan kota kreatif sebagai upaya menciptakan persaingan yang sehat antardaerah. Pada strategi pertama, pemerintah daerah dapat melakukan kolaborasi antaraktor seperti dengan Telkom sebagai penyedia jasa layanan informasi guna melakukan optimalisasi penguatan jaringan terutama pada wilayah-wilayah yang belum ada akses internetnya. Pada strategi kedua, kebijakan penetapan kota kreatif 
sebagai upaya menciptakan persaingan yang sehat antardaerah mampu mendorong terciptanya inovasi-inovasi daerah yang dapat mengoptimalkan pelaksanaan e-government.

Pada strategi ST, strategi yang dapat diterapkan adalah dengan cara pengoptimalan keterlibatan penduduk usia produktif yang tinggi dalam mengatasi ancaman perubahan global yang sangat cepat dan ancaman aspek politik daerah. Penduduk usia produktif merupakan aset pemerintah guna mendukung kemampuan SDM dan e-literacy di masyarakat sehingga pemerintah siap dalam menghadapi perubahan global yang sangat cepat maupun ancaman aspek politik daerah di masyarakat.

Pada strategi WO, terdapat dua strategi yang dapat diterapkan, yaitu program inovasi daerah dan kebijakan e-government guna meningkatkan kemampuan e-literacy dan persaingan yang sehat antarpemerintah daerah akan mendorong peningkatan kualitas SDM yang masih rendah. Kemampuan e-literacy, baik pada aparat Pemerintah maupun pada masyarakat sekiranya mampu diatasi dorongan program inovasi daerah dan kebijakan $e$ government. Program dan kebijakan ini menuntut kemampuan e-literacy guna mengoptimalkan pelaksanaan program e-government. Sama halnya dengan kemampuan $e$ literacy, peningkatan kemampuan SDM aparat pemerintah dituntut untuk terus ditingkatkan seiring dengan perubahan budaya organisasi melalui e-government. Untuk itu persaingan antardaerah yang sehat akan menuntut pemerintah untuk terus mengembangkan kemampuan SDM aparaturnya agar mampu bersaing dengan pemerintah daerah lainnya.

Pada strategi WT, guna meminimalisir perubahan global yang sangat cepat, pemerintah daerah dituntut untuk terus mengembangkan kemampuan SDM dan meningkatkan kemampuan e-literacy. Pada tahapan strategi ini, pemerintah daerah dapat melakukan peningkatan kualitas SDM dan kemampuan e-literacy dengan cara studi banding dengan pemerintah daerah lainnya, training of trainers, dan melakukan sosialisasi ke masyarakat.

Dampak dari inovasi yang telah dilakukan oleh pemerintah daerah melalui kolaborasi dan e-literacy, yaitu tercapai pemerintahan yang akuntabel, transparan, efektif dan efisien, serta meningkatnya partisipasi masyarakat dalam pembangunan dan sistem pemerintahan. Selain itu, inovasi juga dapat membangun sinergitas antara ketiga aktor publik yaitu pemerintah, swasta, dan masyarakat. Sebagai contoh, inovasi dalam sistem pemerintahan telah dilakukan oleh Pemerintah Kota Surabaya melalui aplikasi e-Wadul. Aplikasi ini dapat digunakan oleh warga Kota Surabaya untuk melaporkan segala bentuk tindakan, baik pemerintah maupun pelayanan publik sehingga berpengaruh pada perbaikan kualitas sistem pemerintahan Kota Surabaya dan meningkatkan partisipasi masyarakat.

\section{Tahapan Pengembangan Inovasi e-Government}

Untuk menjawab tantangan dan hambatan dari pengembangan inovasi implementasi e-government pada pemerintah daerah, perlu adanya suatu inovasi perubahan yang dilakukan. Cara yang dilakukan adalah dengan kolaborasi yang baik antara pemerintah dan masyarakat/swasta. Dalam hal peningkatan partisipasi masyarakat, perlu adanya inovasi dalam bentuk e-literacy melalui penyediaan sarana dan prasarana yang dapat memberikan informasi secara bebas, luas, dan merata. E-literacy juga memberikan peluang terhadap masyarakat untuk berpartisipasi dalam pengembangan kebijakan pemerintah daerah (Nurdin et al., 2012: 10).

E-literacy atau digital literacy merupakan suatu kemampuan penggunaan teknologi digital, alat komunikasi atau jaringan internet untuk menemukan, evaluasi, menggunakan, dan membuat informasi. E-literacy juga termasuk kemampuan untuk memahami dan menggunakan informasi dalam berbagai bentuk/media yang berasal dari berbagai sumber 
dengan memanfaatkan penggunaan komputer secara efektif dalam lingkungan digital. Secara garis besar, setiap kemampuan dalam membaca dan memahami media untuk menghasilkan data atau gambar melalui kegiatan digitalisasi serta untuk mengevaluasi dan mengaplikasikan pengetahuan yang baru dalam perkembangan dunia digital (Osterman, 2012: 137).

Tahapan strategi inovasi e-government pemerintah daerah ditujukan untuk mencapai misi e-government itu sendiri yaitu menyelenggarakan Pemerintahan yang akuntabel, transparan, efektif dan efisien serta untuk meningkatkan partisipasi masyarakat dalam pembangunan sesuai dengan Instruksi Presiden No. 3 Tahun 2003. Tahapan pengembangan inovasi tersebut dapat dilakukan melalui kolaborasi dan e-literacy berdasarkan pemetaan SWOT pada Tabel 2 dengan membandingkan antara dua Pemerinah Daerah yang lebih dahulu berhasil dengan pemerintah daerah yang baru akan mengembangkan e-government.

Tahapan kolaborasi yang dilakukan oleh pemerintah daerah bisa dilakukan dengan pihak swasta atau BUMN, terutama dalam penyediaan sarana dan prasarana. Kolaborasi ini akan sangat membantu pemerintah terutama dalam keterbatasan finansial/Anggaran Pendapatan Belanja Daerah (APBD) terutama pada wilayah-wilayah kepulauan dan terpencil. Guna membagi resiko dan keuntungan dari kolaborasi antara Pemerintah dan Swasta, bentuk kolaborasi yang bisa diadopsi dalam hal ini adalah public-private partnership (Manurung \& Anza, 2017: 13; dan Maulana et al., 2019: 410).

Kolaborasi tidak hanya dilakukan antara pemerintah dengan swasta, tetapi juga dilakukan antara pemerintah dan pemerintah. Penguatan antarinstansi pemerintah memberikan dampak tidak langsung terhadap lingkungan, seperti meningkatkan motivasi SDM. Dampak peningkatan yang tidak langsung terhadap SDM mampu memengaruhi secara langsung meningkatnya inovasi pemerintah daerah (Asmara \& Rahayu, 2019: 62). Peningkatan kompetensi SDM terhadap e-literacy juga bisa dilakukan dengan kolaborasi antarpemerintah melalui pelatihan/pendidikan/scholarship yang diadakan oleh Pemerintah Pusat, seperti Badan Perencanaan Pembangunan Nasional (Bappenas). Selain itu, inovasi kolaborasi yang dapat dilakukan oleh pemerintah daerah adalah dengan melakukan kerjasama dengan pemerintah daerah yang telah berhasil melakukan inovasi melalui benchmarking (studi banding). Membangun kerjasama dengan pemerintah daerah yang lebih dahulu maju merupakan salah satu bentuk kolaborasi.

Rendahnya e-literacy di masyarakat yang memengaruhi rendahnya partisipasi masyarakat dalam Pemerintahan merupakan sebuah tantangan yang sangat besar. Guna meningkatkan e-literacy di masyarakat, langkah utama yang harus dilakukan adalah sosialisasi di masyarakat. Keefektifan model sosialisasi akan sangat memengaruhi keberhasilan prosesnya di masyarakat. Model yang efektif diterapkan dalam meningkatkan e-literacy adalah mampu melihat kondisi kekhasan/kearifan lokal suatu wilayah, sehingga sosialisasi $e$-literacy bisa dilakukan melalui budaya (ketua adat), agama (pemuka agama), atau sektor Pemerintahan terendah di masyarakat (RT/Rukun Tetangga). Dalam konsep sosialisasi $e$-literacy ini, pemerintah juga melakukan kolaborasi dengan tujuan memfasilitasi komunitas/masyarakat dalam menyampaikan ide, pendapat atau kritik dalam pengambilan keputusan atau kebijakan (Antoni et al., 2018: 71). Selain itu, peningkatan e-literacy terhadap SDM pemerintah dapat dilakukan melalui kegiatan training of trainers. Jumlah usia produktif yang tinggi, baik di Kota Ternate maupun Kabupaten Buru bisa menjadi peluang atas susksesnya penerapan e-literacy di masyarakat.

Oleh karena itu, dalam mengembangkan inovasi e-government secara efektif, pemerintah daerah disarankan harus melaksanakan strategi percepatan pembuatan peraturan perundang-undangan dan kebijakan untuk mendukung e-government di daerah; pengadaan 
sarana-prasarana pengembangan infrastruktur untuk menciptakan akses komunikasi data yang handal; pemberdayaan sumber daya manusia dan/atau kerja sama dengan swasta/masyarakat dalam penyediaan akses komunikasi data yang mudah nyaman dan dengan biaya terjangkau; pengembangan sumber daya manusia dalam pengelolaan dan penggunaan e-government; pengembangan perangkat-perangkat lunak yang diperlukan; dan pengembangan organisasi dan tata kerja yang mendukung e-government (Presiden Republik Indonesia, 2003: 5; Hardjaloka, 2014: 451; dan Maulana et al., 2019: 411).

\section{E. PENUTUP}

Hasil analisa menunjukkan bahwa masih rendahnya pelaksanaan inovasi daerah mempengaruhi rendahnya pelaksanaan e-government pada pemerintah daerah. Strategi yang dapat dilakukan oleh pemerintah daerah dalam mengembangkan inovasi $e$ government dapat melalui kolaborasi dan e-literacy. Kolaborasi dapat dilakukan dengan pihak ketiga/swasta untuk mengatasi masalah finansial. Selain itu, kolaborasi yang dilakukan antarinstansi bertujuan untuk penguatan intansi terkait dalam pengembangan $e$ government. Proses kolaborasi dengan pemerintah daerah yang lebih dahulu berkembang dalam inovasi e-government dapat dilakukan melalui proses studi banding. Kegiatan $e$ literacy dapat dilakukan untuk meningkatkan partisipasi masyarakat dalam pemerintahan dengan cara melakukan sosialisasi dengan memperhatikan kondisi kekhasan/kearifan lokal sehingga sosialisasi bisa dilakukan melalui budaya (ketua adat), agama (pemuka agama), dan unsur Pemerintahan terendah (RT). Peningkatan $e$-literacy pada SDM Pemerintah dapat dilakukan melalui kegiatan training of trainers.

\section{DAFTAR PUSTAKA}

Andhika, L. R. (2018). Elemen dan Faktor Governansi Inovasi Pelayanan Publik Pemerintah. Inovasi Pembangunan: Jurnal Kelitbangan, 6(03), 207-222. https://doi.org/10.35450/jip.v6i03.112

Anonim. (2019a). Kepala BAPPEDA Kabupaten Buru, Najib Hentihu,SP.M.Si gagas inovasi BUKA DATA (Buru Kalesang Data) dalam Diklat Kepemimpinan Tingkat II Angkatan XVI Provinsi Maluku Tahun 2018.

Anonim. (2019b). Ternate Smart Island.

Antoni, D., Akbar, M., \& Fatoni. (2018). Electronic Government Rukun Tetangga Model. Jurnal Sistem Informasi (Journal of Information System), 14(2), 64-73. https://doi.org/https://doi.org/10.21609/jsi.v14i2.661

Asmara, A. Y., \& Rahayu, A. Y. S. (2019). Inovasi Pelayanan Kesehatan Gancang Aron di Kabupaten Banyuwangi Dalam Perspektif Matrik Inovasi Sektor Publik. JPSI (Journal of Public Sector Innovations), 03(2), 57-67. https://doi.org/10.26740/jpsi.v3n2.p57-67

Badan Pusat Statistik (BPS). (2019a). Kabupaten Buru Dalam Angka. 81040.1902. Namlea: BPS Kabupaten Buru.

Badan Pusat Statistik (BPS). (2019b). Kota Ternate Dalam Angka (Ternate Municipality in Figure). 82710.1903. Ternate: BPS Kota Ternate. Retrieved from https://ternatekota.go.id/smart-island.tte

Cornell University, INSEAD, \& WIPO. (2019). Global Innovation Index 2019: Creating Healthy Lives-The Future of Medical Innovation. (S. Dutta, B. Lanvin, \& S. WunschVincent, Ed.) (12th Editi). Geneva: World Intellectual Property Organization (WIPO).

Dwiyanto, A. (2015). Manajemen Pelayanan Publik: Peduli, Inklusif, dan Kolaboratif Edisi Kedua.Yogyakarta: UGM Press

Fanani, A. (2019). Banyuwangi Kembali Jadi Kabupaten Terinovatif se - Indonesia. 
Retrieved from https://news.detik.com/berita-jawa-timur/d-4737369/banyuwangikembali-jadi-kabupaten-terinovatif-se-indonesia

Farazmand, A. (2004). Sound Governance in the Age of Globalization. In Sound governance: policy and administrative innovations (First, hal. 19). United State of America: Praeger Publisher.

Fikri, H. (2017). Inovasi Pemerintahan Kabupaten Banyuwangi Melalui City Branding “ The Sunrise Of Java" Sebagai Strategi Pemasaran Pariwisata. ARISTO (Sosial Politik Humaniora), 05(02), 332-344. https://doi.org/10.24269/ars.v5i2.513

Hardjaloka, L. (2014). Studi Penerapan E-Government di Indonesia dan Negara Lainnya sebagai Solusi Pemberantasan Korupsi di Sektor Publik Implementation Study on EGovernment in Indonesia and Other Countries As A Solution in Eradicating Corruption in Public Sector). Jurnal Rechts Vinding, 3(3), 435-452.

Jahidi, I., \& Budiati, A. (2019). The Improvement of E-administration in Indonesia: An analysis based on U theory. In 1st International Conference on Administration Science (ICAS 2019) (Vol. 343, hal. 543-547). Bandung: Atlantis Press. https://doi.org/https://doi.org/10.2991/icas-19.2019.113

Kementerian Pendayagunaan Aparatur Negara dan Reformasi Birokrasi. (2019). TOP 99 Inovasi Pelayanan Publik Tahun 2019. Diambil dari https://www.menpan.go.id/site/publikasi/unduh-dokumen/surat/file/6045-daftar-top99-sinovik-tahun-2019

Kementerian Sekretariat Negara. (2017). Peraturan Pemerintah Nomor 38 Tahun 2017 tentang Inovasi Daerah. Jakarta. Diambil dari http://setkab.go.id/wpcontent/uploads/2017/09/PP Nomor_38 Tahun_2017.pdf

Manurung, L., \& Anza, F. A. (2017). Development of E-government through Public-Private Partnerships in Indonesia. In First International Conference on Administrative Science, Policy and Governance Studies (1st ICAS-PGS 2017) and Second International Conference on Bussiness Administration and Policy (2nd ICBAP 2017) (Vol. 167, hal. 10-17). Jakarta: Atlantis Press. https://doi.org/10.2991/icaspgs-icbap-17.2017.2

Marsaoly, R. (2019). Kolaborasi: Menuju Ternate Kota Kreatif. Retrieved from https://jalamalut.com/2019/05/14/kolaborasi-menuju-ternate-kota-kreatif/

Maulana, R. Y., Bafadhal, F., Agnes, S., Andayani, P., \& Nisa, N. (2019). Strengthening Collaborative Government in The Open Government Era Based on The Utilization of E-Government in Jambi Province. In International Conference on Governance Innovation and Social Sciences (ICOGISS) (hal. 401-413). Jember: Program Studi Ilmu Pemerintahan Fakultas Ilmu Sosial dan Ilmu Politik Univeristas Muhammadiyah Jember. https://doi.org/10.1080/01900692.2016.1263659

Muflihah, Y., \& Susanto, T. D. (2017). Faktor yang Mempengaruhi Warga dan Pemerintah dalam Adopsi E-Government: Sebuah Ulasan Sistematis. Jurnal Teknologi Informasi dan Ilmu Komputer (JTIIK), 4(4), 304-310. https://doi.org/10.25126/jtiik.201744366

Njenga, J. K. (2018). Digital Literacy: The Quest of an Inclusive Definition. Reading \& Writing - Journal of the Reading Association os South Africa. https://doi.org/10.4102/rw.v9i1.183

Novita, D. (2014). Faktor-Faktor Penghambat Pengembangan E-Government : Studi Kasus Pemerintah Kota Palembang, Sumatera Selatan. Eksplora Informatika, 4(1), 43-52. Diambil dari https://eksplora.stikom-bali.ac.id/index.php/eksplora/article/view/94

Nurdin, N., Stockdale, R., \& Scheepers, H. (2012). Benchmarking Indonesian Local Egovernment. In Proceedings - Pacific Asia Conference on Information Systems, PACIS 2012. Ho Chi Minh City: AIS Publisher. Diambil dari 
https://researchbank.swinburne.edu.au/items/7f0ffc71-19aa-4200-91b365cef29f $22 \mathrm{ad} / 1 /$

Ordiyasa, I. W. (2015). Kegagalan Penerapan E-Government di Negara-negara Berkembang. In Seminar Nasional Teknologi Informasi dan Multimedia (hal. 55-60). Yogyakarta: STMIK AMIKOM Yogyakarta. https://doi.org/ISSN : 2302-3805

Osterman, M. D. (2012). Digital Literacy: Definition, Theoretical Framework, and Competencies. In Proceedings of the 11th Annual College of Education \& GSN Research Conference (hal. 135-141). Miami: Florida International University. Diambil dari https://digitalcommons.fiu.edu/sferc/2012/2012/6/

Potter, J. (2004). Theory of Media Literacy : A Cognitive Approach. University of Michigan: Sage Publications

Presiden Republik Indonesia. (2003). Instruksi Presiden Republik Indonesia No.3 Tahun 2003 Tentang Kebijakan dan Strategi Nasional Pengembangan E-Government. Jakarta.

Ramdhani, A., Ramdhani, M. A., \& Amin, A. S. (2014). Writing a Literature Review Research Paper : A step-by-step approach. International Journal of Basics and Applied Sciences, 03(01), 47-56. https://doi.org/10.1177/0021886391273004

Rangkuti, F. (2004). Analisis SWOT Teknik Membedah Kasus Bisnis (11 ed.). Jakarta: PT. Gramedia Pustaka Utama.

Rukmananda, N. (2017). Kota Surabaya Raih Penghargaan "Global Green City" PBB. Retrieved from https://www.voaindonesia.com/a/kota-surabaya-raih-penghargaanglobal-green-city-pbb/4095316.html

Sabaruddin, A. (2015). Manajemen Kolaborasi Dalam Pelayanan Publik. Yogyakarta: Graha Ilmu

Sari, T. P., \& Isnaeni, R. (2019). E-Government: Teknologi Melawan Korupsi. Jurnal Teknologi Informasi ESIT, XIV(02), 83-88.

Secker, J., \& Coonan, E. (2013). Rethinking Information Literacy: A Pratical Framework for Supporting Learning. London: Facet Publishing

Sitokdana, M. N. N. (2019). Evalution of The Information Quality of E-Government Websites of The Provincial Governments of Eastern Indonesia. In International Conference of Organizational Innovation (ICOI 2019) (Vol. 100, hal. 231-241). Ulsan: Atlantis Press. https://doi.org/https://doi.org/10.2991/icoi-19.2019.40

Snyder, H. (2019). Literature review as a research methodology: An overview and guidelines. Journal of Business Research, 104(August), 333-339. https://doi.org/10.1016/j.jbusres.2019.07.039

Sulistiyani, E., \& Susanto, T. D. (2018). A Conceptual Model of Change Management for E-Government Project in Indonesia. In The 4th International Seminar on Science and Technology (hal. 39-42). Surabaya: Postgraduate Program Institut Teknologi Sepuluh November, Surabaya, Indonesia. https://doi.org/10.12962/j23546026.y2019i1.5104

Tomaszewicz, A. A. (2015). The impact of digital literacy on e-government development. Online Journal of Applied Knowledge Management The impact of digital literacy on egovernment development, 3(2), 45-53. Diambil dari http://www.iiakm.org/ojakm/articles/2015/volume3_2/OJAKM_Volume3_2pp4553.pdf

United Nations. (2018). ANNEXES - 2018. United State of America. Diambil dari https://publicadministation.un.org/egovkb/en-us//Reports/UN-E-Government-Survey$\underline{2018}$

Widodo, N. (2019). Innovation Patterns of Local Government in Handling Community Complaints Based on Information Systems. In Annual International Conference of 
Business and Public Administration (AICoBPA) (Vol. 93, hal. 158-164). Malang: Atlantis Press. https://doi.org/ISSN. 2352-5428

Wijaya, A. A. M., Sa'ban, L. A., \& Mayunita, S. (2019). Collaborative Governance to Evolve Smart City in Local Governments. In International Conference on Governance Innovation and Social Sciences (ICOGISS) (hal. 275-286). Jember: Program Studi Ilmu Pemerintahan Fakultas Ilmu Sosial dan Ilmu Politik Univeristas Muhammadiyah Jember. https://doi.org/http://dx.doi.org/10.32528/pi.v0i0.2496

Yudha, H., \& Susanto, T. D. (2019). E-Leadership: The Effect of E-Government Success in Indonesia. In International Conference on Electronics Representation and Algorithm (ICERA 2019) (Vol. 1201, hal. 1-7). Yogyakarta: Journal of Physics: Conference Series. https://doi.org/10.1088/1742-6596/1201/1/012025

Yunita, N. P., \& Aprianto, R. D. (2018). Kondisi Terkini Perkembangan Pelaksanaan EGovernment di Indonesia: Analisis Website. Seminar Nasional Teknologi Informasi dan Komunikasi, 2018(Sentika), 329-336. Diambil dari https://fti.uajy.ac.id/sentika/publikasi/?page=Publikasi\&sub=2018 
